6

\title{
Blackstone, Parliamentary Sovereignty and his Irish Critics
}

\author{
ULTÁN GILLEN
}

Sir William Blackstone, quite naturally, did not devote a great deal of attention to Ireland in his Commentaries on the Laws of England. However, the little he did write specifically about Ireland, and a number of his other claims about the power of parliament and the permissibility of penal legislation against Catholics, provoked controversy and criticism in Ireland. Blackstone was widely read amongst the educated elite in Ireland as in Britain, and this was an important motivation for his critics, who felt his prominence made it important that his arguments be challenged. At the heart of Irish discussions of Blackstone lay the question of parliamentary sovereignty, or, more precisely, the competing claims to sovereignty over Ireland of the British parliament at Westminster and the Irish parliament in Dublin's College Green. Once this question had seemingly been settled in favour of the Irish parliament with the so-called Constitution of 1782 and Westminster's 'Renunciation Act' of 1783, Blackstone was called upon to help make their case by both the advocates and opponents of key political questions, such as parliamentary reform. When - in the aftermath of the failed 1798 United Irish rebellion backed by revolutionary France - the government pushed for a union between Ireland and Great Britain, Blackstone's writings on the powers of parliament and the passing of the Scottish union ensured that he became a source of discussion and controversy once more. Blackstone's Commentaries were of course regularly referred to during legal cases, but these fall outside the scope of this essay, which focuses on 
Blackstone's place in Irish political argument. This essay draws overwhelmingly on pamphlet literature, though some of the pamphlets used first appeared as series of letters in newspapers, while others, for example parliamentary speeches, were also reported in the press. ${ }^{1}$ Discussions about Blackstone were therefore familiar to a range of opinion far beyond the political elite, and arguments about him informed popular works. Irish political commentary on Blackstone was uneven, spiking at times when the powers of the Irish parliament were most in dispute, and not always in much depth, but the range of issues for which Blackstone was put to use is a demonstration of how influential his Commentaries were perceived to be, and his reputation even among his critics.

Blackstone published the first book of the Commentaries in 1765 because of the threat of an unauthorised Dublin edition. ${ }^{2}$ This demonstrated not just the opportunism of Irish publishers exploiting their legally distinct status from Britain, but also Blackstone's standing in Ireland even before the Commentaries were published. A Treatise on the Law of Descent in Fee-Simple had already been published in Dublin in 1760, and other works appeared following publication of the Commentaries. ${ }^{3} \mathrm{His}$ reputation was high in both academic and legal circles, partly due to the large numbers of Irish lawyers and politicians - two often overlapping groups - who had received at least some of their education in England. The Regius professor of law at Trinity College, Dublin, Francis Stoughton Sullivan cited Blackstone as an inspiration for his own efforts to improve the study of law within the university. ${ }^{4}$ The Commentaries quickly established themselves as a key part of the reading of educated Irishmen. A

\footnotetext{
${ }^{1} \mathrm{~A}$ word search for 'Blackstone' and 'Commentaries' in the online databases, the Irish Newspaper Archive and the Act of Union Virtual Library (www.actofunion.ac.uk), turned up little newspaper material. These searches missed some pieces mentioning Blackstone later collected in pamphlet form, and it is possible that a more systematic search of the newspapers would reveal a greater engagement with Blackstone. My impression, however, is that it would not overturn the core arguments here about the timing of the major periods of engagement with Blackstone, nor about the nature of that engagement. ${ }^{2}$ W Prest, 'Blackstone, Sir William (1723-1780)', Oxford Dictionary of National Biography, ed HCG Matthew and B Harrison (Oxford, 2004).

${ }^{3}$ An Analysis of the Laws of England in 1766 and Law Tracts by William Blackstone in 1767.

${ }^{4}$ F S Sullivan, An Historical Treatise on the Feudal Law, and the Constitution and Laws of England (Dublin, 1772) 10. See also, SP Donlan, “"The Places Most Fit for this Purpose”: Francis Stoughton Sullivan and Legal Study at the University of Dublin (1761-66)' (2005) 20 Eighteenth-Century Ireland/Iris an Dhá Chultur 120-139.
} 
Dublin edition of book one appeared in 1766, with all four volumes of various editions published in at least 1769-70, 1773, 1775, 1788, 1794, and 1797.English works critical of Blackstone were also printed in Dublin. ${ }^{5}$ Blackstone was taken as authoritative on purely legal matters, but not on politics.

\section{BLACKSTONE ON IRELAND}

An early, and dramatic, criticism of Blackstone occurred in the Irish House of Commons in March 1771. Richard Power, king's counsel and MP for Tuam, ranted like 'a Bedlamite', damaging his copy of book I of the Commentaries by hammering it against the benches, much to the amusement of those watching. The records are scanty, but Power was complaining about interference from another country, suggesting that, even though he was a government supporter, it was likely Blackstone's assertion of British sovereignty over Ireland that so infuriated him. ${ }^{6}$ This was certainly the question on which the most serious Irish engagement with Blackstone occurred.

When Blackstone was writing, British-Irish relations were defined by two pieces of legislation, one Irish and one British. Poynings' Law, passed by the Irish parliament in 1494, meant that proposed Irish legislation (heads of bills) had to be approved, and could be altered, by the privy council in London, before the Irish parliament had to vote to accept or reject them without further alteration. ${ }^{7}$ The Declaratory Act passed by Westminster in 1719 (6 Geo. I, c. 5: An Act for the Better Securing the Dependency of the Kingdom of Ireland upon the Crown of Great Britain), explicitly stated

\footnotetext{
$5 \mathrm{~J}$ Bentham, A Fragment on Government; being an examination of what is delivered, on the subject of government in general in the introduction to Sir William Blackstone's Commentaries: with a preface, in which is given a critique of the work at large (London, 1776) and Joseph Priestley's Remarks on Some Paragraphs in the Fourth Volume of Dr Blackstone's Commentaries on the Laws of England Relating to the Dissenters (London, 1770) both appeared in Dublin editions the year they were published, but neither was cited by Blackstone's Irish critics

${ }^{6}$ Baratariana (Dublin, 1772) 152, 271 (Barataria was an allegorical name used for Ireland, especially before the Irish parliament accepted the legitimacy of newspapers reporting its proceedings.)

${ }^{7}$ On the operation of Poynings' Law in the eighteenth century, see J Kelly, Poynings' Law and the Making of Law in Ireland, 1660-1800 (Dublin, 2007).
} 
Westminster's right to pass laws that applied to Ireland, thus further enshrining the subordinate status of the Irish parliament and courts. These laws, and the assumptions behind them, shaped Blackstone's few pages on Ireland in section IV of book I of the Commentaries, 'Of the Countries Subject to the Laws of England'.

To Blackstone, Ireland was a distinct but subordinate kingdom. Making a common but false claim that the Irish were for the most part the descendants of the English who helped Henry II undertake what Blackstone considered the conquest of Ireland, he stated they had brought the laws of England with them, and that these had been accepted by the Irish parliament, citing Coke as his authority. ${ }^{8}$ The Gaelic Brehon law had been replaced with English law by King John 'in right of the dominion of conquest'. Because Ireland had its own parliament, Blackstone stated that no laws made in England applied there except for those that named Ireland explicitly, or that applied to all the king's dominions. Ireland's dependent status obliged it to conform to the will or law of its superior:

the original and true ground of this superiority is the right of conquest: a right allowed by the law of nations, if not by that of nature; and founded upon a compact either expressly or tacitly made between the conqueror and the conquered, that if they will acknowledge the victory for their master, he will treat them for the future as subjects, and not as enemies.

However, Blackstone believed that by the early eighteenth century many Irish had forgotten this 'compact', and were challenging the jurisdiction of the British House of Lords, leading to the possibility of the law being changed without the assent of the superior power, and of legal judgments diminishing the dependence of Ireland upon the Crown of Great Britain. All this rendered the Declaratory Act a necessity. ${ }^{9}$

\footnotetext{
${ }^{8} \mathrm{~W}$ Blackstone, Commentaries on the Laws of England, Book I: Of the Rights of Persons, ed D Lemmings and W Prest (Oxford, 2016), 71 [98-99]; here and below, pagination of the original (1765-69) edition is given in square brackets. A likely source for Blackstone's claim about the composition of the Irish population was W Molyneux, The Case of Ireland's Being Bound by Acts of Parliament in England, Stated (Dublin, 1698) 20.

${ }^{9}$ Blackstone, Commentaries vol 1, 71-74 [99-102]. On the Act, see I Victory, 'The Making of the 1720 Declaratory Act' in G. O'Brien (ed), Parliament, Politics and People: Essays in Eighteenth-Century Irish History (Dublin, 1989) 10-29.
} 
Understanding Irish reactions to Blackstone requires an understanding of the arguments of William Molyneux, who for Irish patriots had already explained the true nature of the British-Irish relationship, how it violated the rights of Ireland, and how to fix it. Molyneux's Case of Ireland Stated (1698) argued that there had not been a conquest, but a voluntary submission to Henry II. Even if there had been, the Irish were now mostly the descendants of those who conquered with Henry, and enjoyed the rights of Englishmen, and of their own constitution of Ireland's king, lords and commons. Molyneux also used the doctrine of rights lately employed by his friend John Locke to argue against any right of conquest. He provided a ready-made set of historical and theoretical arguments with which to refute Blackstone.

When it came to Ireland's relationship with Britain, Bentham's criticism that Blackstone justified everything that was as being as it should be might be said to apply. ${ }^{10}$ Blackstone supported the British interpretation of the relationship, asserting Westminster's legislative and judicial power, and criticising Irish counter-claims. In relying on the right of conquest, Blackstone was sure to meet opposition. However, sustained criticisms of Blackstone would not appear in Ireland for a decade, and when they did, they would, initially at least, be connected with the question of religion.

\section{CRITICS OF BLACKSTONE ON RELIGION IN IRELAND}

Blackstone's comments about the relationship between citizenship and religion in book IV were the target of these criticisms. Ireland's confessional state discriminated against both Catholics - who comprised around 75 to 80 per cent of the population - and Protestant Dissenters, primarily Presbyterians, who made up around 10to 15 per cent.. Both were denied full political rights, which were enjoyed only by the adherents of the Established Church of Ireland (an Anglican church). Catholics, unlike Presbyterians, were denied the vote, but both were barred from holding public office. The rights of Catholics to own land were severely restricted: they were prohibited from buying land, and Catholic-owned land was vulnerable - theoretically at least - to seizure. Neither Catholic nor Dissenting marriages were recognised by the state. While restrictions on

\footnotetext{
${ }^{10}$ Bentham, Fragment on Government xiv.
} 
'unofficial' religions were of course normal throughout Europe at this time, they usually applied to minority groups and not as in Ireland to the majority of the population. ${ }^{11}$

Despite the penal laws, the remnants of the Catholic gentry and the episcopacy formed the basis for a Catholic leadership that preached loyalty to the state. With the ideas of the Enlightenment concerning religious toleration making an impact on Ireland, a Catholic Committee had been formed in 1757 to lobby for Catholic relief. ${ }^{12}$ Catholic activists proposed a number of oaths of allegiance that they felt would preserve their religion intact while allowing them to demonstrate loyalty to the state. They also wrote a number of histories of Ireland intended to counter the beliefs that Catholics were inherently disloyal, and that they sought both to extirpate Protestantism and reclaim the land lost by their ancestors. It was in this context, with an oath of allegiance having been accepted by the Irish parliament in 1774, that Catholic writers criticised Blackstone's opinions on religion. The acceptance of this oath by parliament merely signified a belief that Catholics could be loyal, and did not result in the repeal of any penal laws, or the opening of public office to Catholics.

When it came to the religious establishment, Blackstone's Commentaries declared that '[e]very thing is now as it should be'. ${ }^{13}$ Blackstone meant that the Established Church successfully avoided the excesses of both its Dissenting and Catholic rivals. They wished to establish a supremacy of their own, and thus to encroach on rights which 'reason and the original contract of every free state in the universe have vested in the sovereign power. ${ }^{14}$ Blackstone supported toleration, but believed that the

\footnotetext{
${ }^{11}$ On the penal laws, see T Bartlett, The Fall and Rise of the Irish Nation: The Catholic Question, 16901830 (Dublin, 1992); SJ Connolly, Religion, Law and Power: The Making of Protestant Ireland, 1660 1760 (Oxford, 1992), and the critique of Connolly in I McBride, Eighteenth-Century Ireland: The Isle of Slaves (Dublin, 2009), chapter 5; J Bergin, E Magennis, L Ní Mhungaile and P Walsh (ed), 'New Perspectives of the Penal Laws', Special Issue no 1, Eighteenth-Century Ireland:Iris an dá chultúr (Dublin, 2011).

${ }^{12}$ On the Enlightenment and Irish politics, see M Brown, The Irish Enlightenment (Cambridge MA, 2016), and U Gillen, 'Varieties of Enlightenment: the Enlightenment and Irish Political Culture in the Age of Revolutions' in R Butterwick, S Davies and G Sanchez Espinosa (ed), Peripheries of the Enlightenment (Oxford, 2008) 163-81.
}

${ }^{13} \mathrm{~W}$ Blackstone, Commentaries on the Laws of England, Book IV: Of Public Wrongs, ed R Paley and W Prest (Oxford, 2016) 32 [49].

14 ibid 68 [103]. 
established church must always enjoy a privileged position. He distinguished between Dissenters and Catholics on the grounds that the Dissenters' beliefs did not 'extend to a subversion of the civil government'. Blackstone, who devoted chapter seven of book IV to praemunire (the offence of asserting papal jurisdiction in England), believed that Catholicism was incompatible with loyalty to the state. Catholics therefore should suffer legal and political disabilities. '[W]hile they acknowledge a sovereign power, superior to the sovereignty of the kingdom, they cannot complain if the laws of that kingdom will not treat them upon the footing of good subjects.' 15 Though he justified the existence of laws against Catholics, Blackstone believed that 'merciless bigots' should not be able to use them against peaceful Catholics causing no trouble. ${ }^{16}$ Blackstone, then, cast doubt on the ability of Catholics to be loyal. Given the status which his Commentaries enjoyed among the elite in both Britain and Ireland, Catholic writers felt they had to challenge his arguments.

In 1775, John Curry, the Catholic Committee activist whose Historical Memoirs of the Irish Rebellion in the Year 1641 (1758) has been described as the 'first major challenge to official anti-Catholicism', published An Historical and Critical Review of the Civil Wars in Ireland. ${ }^{17}$ His aim, Curry explained, was not to inflame religious tensions, but to effect reconciliation by demonstrating, through the primary sources, how accounts of Irish history that emphasised Catholic disloyalty and brutality were wrong. ${ }^{18}$ This led Curry to criticise two of the most prominent figures in the Anglophone intellectual world, David Hume and Blackstone, whose authority and reputation made their misrepresentations all the more dangerous, he said, than those of nakedly anti-Catholic polemicists.

Curry reminded his audience that violence was a constant feature of Irish politics before the Reformation, and so dismissed the idea that Catholicism made the majority violent towards their neighbours. Instead, power struggles had been consistently dressed up as religious disputes. Hume, he said, had had the best of intentions, to urge the Irish

\footnotetext{
15 ibid 35-36 [54].

16 ibid 37-38 [57].

${ }^{17} \mathrm{McBride}$, Isle of Slaves 314.

$18 \mathrm{~J}$ Curry, An Historical and Critical Review of the Civil Wars in Ireland, from the Reign of Queen Elizabeth, to the Settlement under King William. Extracted from Parliamentary Records, State Acts, and other authentic materials (Dublin, 1775), advertisement.
} 
to forget their divisions, but his mistakes were harmful. Similarly, Blackstone had 'enlightened these nations by his admirable commentaries on their laws', but he analysed the possibility of Catholic loyalty in a protestant state in only the most shallow way. With all deference due to 'so great an authority', the Catholics of Canada and Hanover disproved his assertions of inherent Catholic disloyalty. As far back as Elizabeth's reign, Curry stated, Catholics had proven loyal to their monarch while accepting the pope as their spiritual leader. Irish Catholics had just recently drawn up an oath showing exactly this. Anyone who knew anything about the Catholic absolutist states of Portugal, Spain and France knew that the notion that Catholics owed their first loyalty to the pope was laughable. It was a pity that Blackstone's failure to grasp this fact, so easily within his reach, lent credibility and longevity to a damaging falsehood. ${ }^{19}$ While emphasising his respect for Blackstone's authority on the law and constitution, Curry effectively accused him of failing to apply any analytical power to the Catholic question, and of relying instead on the 'first impressions' he had received on the issue. ${ }^{20}$ Blackstone, in other words, had been derelict in his intellectual duty, preferring prejudice to reason.

An anonymous pamphlet opposing the penal laws also explicitly criticised Blackstone .It was largely composed of selections from the works of others linked together by its own arguments, so much so that the author inserted a denial of plagiarism. ${ }^{21}$ The two great evils facing Ireland were said to be the penal laws and attempts to render the Irish abject servants of others. The anonymous author cited Thomas Leland's History of Ireland from the invasion of Henry II, with a preliminary discourse on the ancient state of that kingdom (1773) on the question of a conquest. Leland, the librarian of Trinity College, dismissed the idea of a conquest as 'ridiculous flattery' of Henry II by courtiers like Geraldus Cambrensis. Leland explicitly refuted the claim of Blackstone, referred to as 'the professor of laws in the eighteenth century', that

\footnotetext{
${ }^{19}$ ibid xiii-Xvii.

20 ibid XV.

${ }^{21}$ [Anon.], An Inquiry into the Laws Affecting the Popish Inhabitants of Ireland, preceded by a short political analysis of the history and constitution of Ireland, in which the rights of colonists and planters are briefly mentioned, the nature of the connection between England and Ireland deduced from the time of Henry II and a few observations made on the policy of the laws that restrain the trade of Ireland, with some hints respecting America (Dublin, 1775), advertisement.
} 
the English enjoyed the right of conquest over Ireland. Drawing upon Molyneux, he argued that rather than a conquest, there had been a voluntary submission to Henry II. ${ }^{22}$ The Inquiry suggested that Blackstone's assertion of Ireland being conquered stemmed either from ignorance of its history, or from a desire to justify the Declaratory Act 'at the Expense of Truth and his own Conviction'. Blackstone's belief that Ireland had been conquered was particularly surprising given his denial that William had conquered England. ${ }^{23}$ While Curry accused Blackstone of failing to use his reason, the Inquiry implied that Blackstone had deliberately put his prejudices, and perhaps his ambition, before the truth. It was just as well that 'the impotent breath of an English lawyer' could not make vanish 'the great Constitutional Rights of some Millions of loyal Irish Subjects'. Unlike Curry, the Inquiry made its case against the penal laws and for the oath of allegiance without criticising Blackstone's comments on religion. As with Curry, however, it, praised Blackstone, as 'an Ornament to Mankind, and an Honour to his Country', explaining that it was necessary to critique him because 'so great a Man' held such influence. ${ }^{24}$

The Capuchin priest Arthur O'Leary, who returned to Ireland in 1771 following twenty four years in France, quickly established himself as a prominent advocate of the Catholic cause. He supported the 1774 oath of allegiance. ${ }^{25}$ In 1780, the founder of Methodism, John Wesley, wrote to the Dublin newspaper the Freeman's Journal, defending Lord George Gordon's Protestant Association, which had been established to seek the repeal of the Catholic Relief Act of 1778 (18 Geo. III, c. 60) that removed a number of restrictions on Catholic landownership and punishments for Catholic clergy and schoolmasters in England and Wales. Wesley warned that on account of their doctrine that no faith should be kept with heretics, Catholics could give no security for their allegiance, and so should not be trusted with any public or political role by any

\footnotetext{
$22 \mathrm{~T}$ Leland, History of Ireland from the invasion of Henry II, with a preliminary discourse on the ancient state of that kingdom (1773) vol 1, 153. Much of Leland's account is quoted in Inquiry $20 \mathrm{ff}$. 
government Protestant, Mahometan, or Pagan'. ${ }^{26}$ The first of the Catholic Relief Acts for Ireland had also been passed in 1778, allowing Catholics better access to land and to serve in the armed forces, a matter of urgency given the American Revolutionary War. In writing against Wesley, O’Leary both condemned Blackstone's opinions on religion and citizenship, and sought to use Blackstone to support his own cause.

O'Leary constructed his argument from an eclectic mix of sources. Discussing Jan Hus, whose case had provided the original declaration that no faith need be kept with heretics, he essentially gave the contemporary Catholic church's version, namely that Hus had abused the safe conduct promised him by his king to spread doctrines dangerous to church and state, and been punished. ${ }^{27}$ O'Leary said that it was the likes of Hus that Blackstone had in mind when he condemned the 'dreadful effects' of religious bigotry as seen in the Anabaptists in Germany and Scottish Covenanters (O'Leary tactfully omitted Blackstone's reference to the Puritans in 1640s England). ${ }^{28}$

O'Leary also deployed discourse of the Enlightenment to attack Gordon's supporters. 'In an enlightened age, when the cheerful eyes of philosophy and religion cannot bear the sight of frantic fanaticism, banished from all quarters of Europe, it found shelter among you, with its distorted features, and numerous train of calamities and evils.' ${ }^{29}$ If Gordon's claims that Catholics simply did what popes and priests told them, and were not bound by oaths or conscience were correct, then Irish society (and others) could not function. The very existence of functioning polities with majority Catholic populations throughout Europe disproved them, he argued. It was the Protestant Associations who violated the laws of civil society and the sacred rights of nature. ${ }^{30}$ O'Leary was partly responding to Blackstone's claim that Catholics always sought to place themselves

\footnotetext{
${ }^{26}$ A O'Leary, Mr. O'Leary's Remarks on the Rev. John Wesley's Letters in Defence of the Protestant Associations of England. To which are Prefixed, Mr. Wesley's Letters (Dublin, 1780) 2. Wesley's letter dated from January 1780, well before the infamous anti-Catholic Gordon Riots of June.

${ }^{27}$ Remarks 25-31.

${ }^{28}$ Quoted in Remarks 27; Blackstone, Commentaries vol 4, 68-9 [103]. O'Leary also paraphrased some of Blackstone's discussions of penal laws and witchcraft: Commentaries vol 4, 37-40 [56-61]. See Remarks $27-28$, including fn.

29 ibid 54.

30 ibid 55-56.
} 
outside the authority of the civil power. ${ }^{31}$ Blackstone, 'the learned expositor of England's common law', had been ensnared by 'vulgar delusion' when it came to the pope's authority over Catholics in Britain and Ireland, which was spiritual alone. Once again, an Irish critic acknowledged Blackstone's authority on the law, but accused him of failing to move beyond popular prejudices regarding religion, loyalty, and citizenship. A Church of Ireland minister's refutation of O'Leary cited Blackstone's argument in book IV on public wrongs that priests renounced their temporal sovereign on taking orders, reminding us that Blackstone's suspicions were still shared by many Irish protestants. ${ }^{32}$ O'Leary's example of using Blackstone would be followed during a later Catholic campaign.

By 1792, the aristocratic-clerical leadership of the Catholic Committee had been shunted aside by a more militant group dominated by prosperous merchants, several of whom had links to the radical United Irishmen. Hoping ultimately for Catholic emancipation, their immediate goal was the removal of the remaining penal laws and acquisition of the franchise. A large proportion of the political nation reacted angrily, and the doctrine of Protestant Ascendancy - the idea that political power and government offices must remain exclusively in the hands of adherents of the Established Church of Ireland - became a rallying cry for hardline supporters of the status quo. ${ }^{33}$ Sectarian relations worsened, with violence breaking out in some areas. The British government used its influence in the Irish parliament to push through a Catholic Relief Act which opened up the professions and Trinity College Dublin to Catholics, but the vote was withheld amid many warnings in parliament from conservatives that the Catholics should be grateful for this act, and ask for no more. The Catholic campaign continued. The Catholic priest John Nassau used Blackstone to help argue for

\footnotetext{
${ }^{31}$ Blackstone, Commentaries Book IV, ed Paley, $72-78$ [108-18].

32 ['A Protestant Divine of the Church of Ireland'], An Impartial Enquiry; Whether the Two Propositions, to be abjured by the oath of abjuration, are doctrines of the church of Rome (Dublin, 1780) 10.

${ }^{33}$ The term had been employed previously, but its use multiplied in 1792 with grand juries, corporations, and other representative organs launching a concerted campaign to protect it. On the term itself, see J. Kelly, 'Eighteenth-Century Ascendancy: A Commentary' (1990) 5Eighteenth-Century Ireland173-87, and WJ McCormack, The Dublin Paper War of 1786-1788: A Bibliographical and Critical Inquiry (Dublin, 1993) for summaries of their debate on the issue. S Small, Political Thought in Ireland, 17761798: Republicanism, Patriotism and Radicalism (Oxford, 2002) 202-06.
} 
enfranchisement. Nassau sought to prove that enfranchisement would endanger neither church nor state. He used Blackstone's arguments on what it meant to be free (with and without attribution). He deployed Blackstone's argument that for a people to be free they had to compose one branch of the legislature, quoting Blackstone directly. It was 'repugnant to reason' to claim that a people who were taxed and lived under laws made by men who were their masters, and not their representatives, were free. ${ }^{34}$ Nassau therefore used Blackstone to argue, in effect, that the status quo in Ireland violated the basic principles of the constitution. This formed part of a concerted effort by Catholic activists to annex the dominant political language of official Irish political culture to their cause. Following the acquisition of legislative independence in 1782, it became commonplace among both supporters and opponents of government to claim that Ireland now enjoyed all the benefits of the British constitution of 1688, regarded as the best in the world. The Catholics portrayed themselves as seeking the benefits of that constitution, and thus to pre-empt allegations that they sought to overturn it. It made perfect sense to deploy one of the most respected of all commentators on that constitution, even if it was to argue for something that Blackstone had himself opposed.

Nassau sought to annex Blackstone to the Catholic cause, but a more radical pamphleteer singled out Blackstone's influence as one of the things standing in the way of emancipation and parliamentary reform. 'Well-meaning men' depended 'too much on the visionary statement of our constitution, as given by foreigners [ie Montesquieu and De Lolme] and by Blackstone'. People needed to embrace 'a perfect representation of the people' to overcome Ireland's myriad economic, social and religious problems, and no longer allow themselves to be blinded by those like Blackstone who mispresented the corrupt reality of the existing constitution. ${ }^{35}$ This pamphlet was addressed to the Whigs of the Capital, a radical group much less socially elevated than the Irish Whig Club proper, and from which the Dublin United Irishmen emerged. In their official publications, neither the Whigs of the Capital nor the United Irishmen engaged with Blackstone, who stood for the principles of a constitution they sought to

\footnotetext{
${ }^{34} \mathrm{~J}$ Nassau, The Cause of the Roman Catholics Pleaded, in an Address to the Protestants of Ireland (Dublin, 1792) 17-18; Blackstone, Commentaries vol 1, 105-06 [154].

${ }^{35}$ Two Letters to the Whigs of the Capital (Dublin, 1792) 16.
} 
overturn. Discussion of Blackstone was therefore largely confined to those who broadly accepted the constitution, even if they wished to reform it.

\section{IRISH POLITICAL RIGHTS}

Blackstone's attitude to religion and citizenship provoked criticism across several decades, but it was his account of the powers of Westminster that attracted the most criticism in Ireland. This was not just about Westminster's supremacy over Ireland: Blackstone's argument that 'a supreme, irresistible, absolute, uncontrolled authority', an 'absolute, despotic power', must be located somewhere in all governments also proved controversial, especially as so much Irish political discourse was formed of the political languages of ancient constitutionalism, natural rights, and classical republicanism. ${ }^{36}$ Blackstone's statement that while the constitution lasted, 'the power of parliament is absolute and without control' was also a cause of contention, as was his attitude towards 1688 and Locke's Two Treatises of Government (1689). His Irish critics accused Blackstone of understanding neither the constitution nor the principles on which it was based.

Blackstone's most engaged and intellectually sophisticated Irish critic was Charles Francis Sheridan. Sheridan was the son of the famous theatre manager Thomas Sheridan, and brother of the politician and playwright, Richard Brinsley Sheridan. ${ }^{37}$ Like his brother he was a Whig, and became an Irish government official after Lord North's fall in 1781. However, he remained in his post after Pitt came to power, and unlike his brother, he supported Protestant Ascendancy and counter-revolution in the 1790s. When Charles Francis published his Observations on Blackstone's doctrine on the powers of the British parliament in 1779 , he had already established a reputation with his History of the Late Revolution in Sweden (1778), during which he been a part of the British embassy. Having gone to study law in Lincoln's Inn in 1775, Sheridan would be called to the Irish bar in 1780. His account of Gustav III's coup in Sweden in

\footnotetext{
${ }^{36}$ Blackstone, Commentaries vol 1, 39-38, 107 [49, 156]; Small, Political Thought, identifies these as three of the five main political languages of Irish political thought.

${ }^{37}$ EM Johnston-Liik, 'Sheridan, Charles Francis (1750-1806)', Oxford Dictionary of National Biography.
} 
1772 proved his Real Whig credentials (i.e. it emphasised the dangers to liberty from the executive, which must always be treated with extreme suspicion and vigilance if the free government created by the contract between ruler and ruled in 1688 was to be preserved). It explained the revolution and the lack of opposition to it as the result of a free people growing complacent about its liberties and allowing the monarch to corrupt the legislature. The warning about the influence of the crown in Westminster was clear, but made explicit anyway: 'This revolution furnishes us with a striking, and I may add, a useful instance, of the fatal effects of corruption; for even in Great Britain corruption has had its advocates'. ${ }^{38}$ Sheridan's Observations on Blackstone were rooted in the same Real Whig principles, added to those of Irish patriotism. ${ }^{39}$

Sheridan's Observations were published in the middle of a struggle between on the one hand patriot politicians and a mobilised Irish public opinion - represented most obviously and most menacingly by tens of thousands of armed volunteers who had formed as a result of the withdrawal of troops from Ireland to fight in America and then turned their attention to political questions -and the London government on the other. At stake was Westminster's right to legislate for Ireland. The dispute originally centred on laws restricting Ireland's ability to engage in international trade, but it soon encompassed the nature of the connection between the two kingdoms. The demand was not for separation, but legislative independence, i.e. the right of the Irish parliament exclusively to make laws for Ireland. The Irish patriot argument was that the sister kingdoms should be exactly that - equals united by a common monarch and common interests, with neither dominating the other. They sought to enact the constitutional theory of Irish patriotism. Blackstone was therefore a natural target.

\footnotetext{
${ }^{38}$ CF Sheridan, A History of the Late Revolution in Sweden (London, 1778) 402. For further discussion of this work, see Small, Political Thought 91-92, and U Gillen, 'Constructing Counter-Revolutionary History in Late Eighteenth-Century Ireland' in M Williams and SP Forrest (ed), Constructing the Past: Writing Irish History, 1600-1800(Woodbridge, 2010) 140-141.

${ }^{39}$ On eighteenth-century Irish patriotism, see J Leerssen, 'Anglo-Irish Patriotism and its European Context: Notes Towards a Reassessment' (1988) 3 Eighteenth-Century Ireland 7-24; P Kelly, 'William Molyneux and the Spirit of Liberty in Eighteenth-Century Ireland' (1988) 3 Eighteenth-Century Ireland 133-48; SJ Connolly, 'Precedent and Principle: The Patriots and their Critics' in SJ Connolly (ed), Political ideas in Eighteenth-Century Ireland (Dublin, 2000) 130-58.
} 
Sheridan explained that he wished to correct Blackstone's mistaken theory of the constitution. This was all the more pressing because Blackstone's interpretation had gained such wide acceptance, his being the only book on the law read by nonspecialists, and because the country gentlemen who were so vital a part of parliament put so much faith in a writer of his great reputation. Even some of the most zealous adherents of the cause of liberty praised Blackstone's vision of the constitution. The existence of the constitution was dependent upon the public understanding liberty, and if they did not, if they believed that parliament should hold more power than it ought, then Sweden demonstrated what could happen. ${ }^{40}$ Sheridan praised Blackstone's work on the common law in general but his writings on the constitution were 'confused, inconsistent, and ... frequently absurd'. Sheridan insinuated that this was because they had been written with an eye to securing a seat on the bench. ${ }^{41}$ His main target was Blackstone's advocacy of the 'uncontrolled, absolute, despotic power of Parliament'. ${ }^{42}$ To refute Blackstone, Sheridan offered his own analysis of three key areas: the nature of liberty, the true principles of the constitution, and the extent of the power of parliament. In doing so, he provided his own theory of representative government, of the rights of nations, and of the workings of a 'free empire', such as that of which Ireland and Britain ought to be a part. ${ }^{43}$ Sheridan updated Molyneux, but his work offered much more.

To prove Blackstone's inconsistency, Sheridan sat different quotations from Book I of the Commentaries facing each other (editing the quotes when it suited him). For example, he contrasted Blackstone's claim about parliament's power to do anything not naturally impossible with his statement that no human legislature had the power to destroy natural rights, and his claim that if parliament fell into misgovernment, the subjects would be left without remedy, with his list of the means the people had of vindicating their rights, ranging from the law courts to armed rebellion. ${ }^{44}$ Sheridan said

${ }^{40}$ CF Sheridan, Observations of the Doctrine Laid Down by Sir William Blackstone, Respecting the Extent of the Power of the British Parliament, Particularly in relation to Ireland. In a Letter to Sir William Blackstone (Dublin, 1779) 3-4, 24.

41 ibid 6,7,9.

42 ibid 3.

43 ibid 56.

${ }^{44}$ ibid 10-12. 
it was a nonsense to suggest that despotic power could be entrusted, as an entrusted power could be reclaimed, and something that could be reclaimed was by definition not despotic. ${ }^{45}$ Blackstone's arguments were, Sheridan claimed, illogical, and not to be trusted.

To bolster his case that Blackstone misunderstood the constitution, Sheridan turned to a still greater authority, Locke, whose doctrine was, 'the first article in the political creed of every freeman'. ${ }^{46}$ Blackstone accepted in theory Locke's argument that the trust reposed in the legislature reverted to the people when it was abused, but said it could not be accepted in practice, as it would mean the destruction of all existing law, and having to start again from scratch. No society, he said, would agree to this. ${ }^{47}$ Sheridan argued that 1688 proved Locke correct and Blackstone wrong. 1688 had, he said, been exactly a case of power devolving back to the people, and instead of producing a return to the state of nature or the destruction of the constitution, the result was that the rights of the people had been more firmly established. Blackstone's error lay in mistaking the creatures of the constitution - the king, lords and commons - for the constitution itself, and in thinking that changing one meant changing the other. ${ }^{48}$

Sheridan agreed with Blackstone, and so many other constitutional theorists, that the purpose of society was to allow individuals to enjoy their natural rights, even if, highly unusually, Sheridan argued that people did not surrender part of their natural liberty when entering society. ${ }^{49}$ The three primary natural rights were the right of personal security, the right of personal freedom in so far as one did not interfere with the rights of others, and the right of legitimately-acquired private property. 'The full complete possession of these, constitutes liberty. ${ }^{50}$ A fourth natural right implicitly arose from these three, namely the right to repel invasions of these rights. This was the purpose of government, which derived its authority from this fourth right. A government could only be a free government if it lacked the ability to invade these rights itself. ${ }^{51}$ However,

\footnotetext{
45 ibid 14.

46 ibid 20.

${ }^{47}$ Blackstone, Commentaries vol 1, 108 [157].

${ }^{48}$ Sheridan, Observations $20-22$.

49 ibid 31.

50 ibid 34-35.

51 ibid35-36, 41.
} 
the fourth right differed from the others in that it was an act of power and not an act of liberty. ${ }^{52}$ In Britain and Ireland, exercising the fourth right involved elections, which preserved the constitution by guarding against encroachments on the people's rights by the governors. However, any form of limiting the duration of the legislature would do it was the limitation that represented the exercise of the fourth natural right. Blackstone, like many other theorists, was wrong to believe that natural liberty was the freedom to do whatever one pleased regardless of others, and that this was surrendered upon entering society. Violating the natural rights of another, Sheridan said, was an act of power, not of natural liberty. Acts of power were constrained by society, not acts of liberty. ${ }^{53}$

Government must protect, not violate, the rights of the people. Legitimate government required an identity of interest between the represented and their representatives. Without it, representation was an illusion. Sheridan wondered whether an identity of interest simply could not exist between the legislature of one community and the people of another. If not, then a foreign legislature making laws for a people was a usurpation of the fourth natural right that guaranteed a people liberty. In other words, Westminster claiming sovereignty over the people of Ireland, who had delegated the exercise of their fourth natural right to a different parliament, was a violation of their natural rights, and thus illegitimate, the purpose of government being to preserve and not violate natural rights. ${ }^{54}$ Like Molyneux before him, Sheridan therefore opposed the doctrine of natural rights to Westminster's claims to sovereignty over Ireland. Following Molyneux, he used this doctrine against the very idea of a right of conquest. Just as no individual could legitimately invade the rights of another, so too with peoples. Following Molyneux once more, Sheridan said that if the right of conquest did exist, it could not apply to the descendants of the conquerors, who now owned ninety percent of the country. ${ }^{55}$ Sheridan thus dispensed with any grounds for Westminster exercising a legitimate sovereignty over Ireland, and he offered a very different vision to Blackstone's of how the empire should function.

\footnotetext{
52 ibid 52; Sheridan took this idea from Jean-Louis De Lolme.

53 ibid 37-38, 53-54.

54 ibid 54-56.

55 ibid 46-49.
} 
'In a free empire', Sheridan claimed, one community bore the same relation to another as individuals within the same community. A free empire was not one where the largest state was free in itself while being sovereign over the smaller states. ${ }^{56}$ Responding to expected objections that the empire required a strong presiding power and that it must reside in the largest state, Sheridan stated that a free empire meant that the constituent parts acted towards foreign powers as one. It did not mean that there should be an identity of internal government and laws. Such a thing was an absurd suggestion for an empire composed of free peoples with their own legislatures, and could be effected only by 'the iron hand of despotism'. Under the constitution, it was necessary only that each component was intimately connected with the largest state, not dependent on it. They should be linked by the same relation to the supreme executive power that could speak for them all in foreign relations and protect the interests of each community, including from the selfishness of any individual state that might harm the rest. This would be the best guarantee of the unity of the empire. ${ }^{57}$ One need only look at America to see the evil consequences for the empire of Blackstone's 'doctrine of the supremacy and omnipotence of the British Parliament. ${ }^{58}$ One of the reasons for writing his work, Sheridan said, was to persuade those likely to form a future ministry to adopt a different policy to that of Blackstone and Lord North, lest something similar happen in Ireland. 59

Blackstone provided the perfect foil for the arguments Sheridan wanted to make. Sheridan offered a Real Whig view of the constitution and powers of parliament, and an Irish patriot view of Irish history, of the British-Irish relationship, and of how the empire ought to function. Blackstone stood in opposition to all of these, and his prominence made him an attractive target as it would automatically raise the profile of Sheridan's arguments, which, given his unusual take on the nature of liberty, natural rights, and representation, might otherwise have attracted much less attention. Whether Sheridan expected to change the minds of putative future ministers and country gentlemen is questionable, but for an Irish MP with links to the Whigs, criticising

\footnotetext{
56 ibid 56.

57 ibid 61-65.

58 ibid 71.

59 ibid 29-32.
} 
Blackstone perhaps offered a means of attracting attention before the anticipated change of government. Sheridan's criticisms of Blackstone proved relatively popular. They were published in two London editions, in Dublin, and in Cork, and cited by others supporting legislative independence. ${ }^{60}$ Sheridan's was an intellectually ambitious work which drew on a range of political languages, authors, and influences to fashion an original theory of representation as part of a broader statement of the emerging consensus in Irish politics about the preferred relationship with Britain, which it helped to shape.

Other patriots criticised Blackstone on similar grounds. Frederick Jebb, in an influential series of letters written under the name of Guatimozin, the last Aztec emperor, accused Blackstone of justifying a British act of parliament that made the Irish slaves (i.e. the Declaratory Act) to enhance his career. 'What a prostitution of honour, of principles, and of talents!'61 The radical and popular Letters of Owen Roe O'Nial (1779), which exhibited separatist leanings, mocked Blackstone as a 'courtier' who believed authority was always right, and opposition to it rebellion - whether that was the barons of 1215, Martin Luther, or Jesus himself. It argued that Blackstone's logic would render the Irish slaves of the British, to be disposed of as they pleased. ${ }^{62}$ Henry Grattan, the leading figure in the 'revolution of 1782', denounced Blackstone in the Irish parliament for 'childishly' arguing that the connection between Britain and Ireland was one of conquest, not compact. Grattan echoed earlier criticisms that Blackstone never gave Ireland serious consideration, and that he supported a right of conquest that

\footnotetext{
${ }^{60}$ For example, O’Leary, Remarks 41; The Alarm; or, the Irish Spy. In a series of letters on the present state of the affairs of Ireland, to a lord high in the opposition. Written by an ex-Jesuit, employed by his lordship for that purpose (Dublin, 1779) 42-43; TB Clarke, An Essay on the Powers of Parliament, the Right of Making Laws, and the Individual Declarations of this Kingdom. Written by Thomas Brooke Clarke, while a student at Trinity College Dublin, and now addressed to the Right Honourable the Earl of Carlisle (Dublin, 1781) 32.

${ }^{61}$ The Letters of Guatimozin, on the Affairs of Ireland, as first published in the Freeman's Journal, and which having since been re-printed in London, have gone through several editions there. To which a re added, the Letters of Causidicus, that Accompanied the Essays of Guatimozin in their first appearance (Dublin, 1779) 48.

62 J Pollock, Letters of Owen Roe O'Nial ([Dublin] IRELAND, 1779) 13, 22. The place of publication made a political point.
} 
did not exist. ${ }^{63}$ None of his other critics in this period gave Blackstone much detailed thought, but their rejection of his ideas were clear and, like Sheridan's, were rooted in a belief that he supported the usurpation of the rights of the people of Ireland as individuals and as a nation.

Following the 'Renunciation Act', Blackstone largely disappeared from Irish political discourse, though he was called upon occasionally to lend weight to a variety of political arguments. His work was sometimes cited in parliament to support arguments but was not a prominent feature of debates. Blackstone's doctrine that no parliament could bind its successor was used by an Irish patriot to argue against Pitt's commercial propositions, suspected of being the stalking horse for a union. ${ }^{64}$ In 1783 , an advocate of parliamentary reform cited Blackstone's comments that a more complete representation of the people would be welcome. ${ }^{65}$ In the very different circumstances of 1794, two Belfast Whigs trying to steer a path between revolution and counterrevolution cited Blackstone both to call for the abolition of rotten boroughs and oppose universal manhood suffrage. ${ }^{66}$ Others cited him in favour of universal manhood suffrage. ${ }^{67}$ It was only when the existence of the Irish parliament was called into question with the proposal for union in 1798 that Blackstone was drawn on to any significant extent once more.

That December, Edward Cooke, under-secretary in the Irish government, published Arguments for and against an Union, Between Great Britain and Ireland Considered at

\footnotetext{
${ }^{63}$ Parliamentary Register 2nd edn (Dublin, 1784) vol 1, 267.

${ }^{64}$ The Account Settled! Or a Balance Struck between the Irish Propositions agreed to in the House of Commons of Ireland on the 12 th of February 1785, and the English Resolutions entered into by the House of Commons of England on the 30th of May 1785 (Dublin, 1785) 52, citing Blackstone, Commentaries vol 1, 66 [90].

${ }^{65}$ Letter to Henry Flood, Esq. on the Present State of Representation in Ireland (Belfast, 1783) 18 citing Blackstone, Commentaries vol 1, 113-14 [166].

${ }^{66}$ Belfast Politics (Belfast, 1794) 234-41, citing Blackstone, Commentaries vol 1, 113-15 [165,168].

${ }^{67} \mathrm{~W}$ Drennan, A Letter to his Excellency Earl Fitzwilliam, Lord Lieutenant \& c. of Ireland (Dublin, 1795)

47; [A Citizen], Observations on the Meaning of the Words Protestant Ascendancy and Orangemen; including some strictures on other parts of, the answer of Patrick Duigenan, LLD Justice of the
} Prerogative Court, to Mr. Grattan. Addressed to the Learned Doctor (Dublin, 1798) 52-54 argued that Blackstone had in Commentaries vol 1, 113 [165] admitted the principle of people being represented, not property. 
the behest of William Pitt, who wished to seize the opportunity to enact a union. ${ }^{68}$ Cooke sparked an enormous, and enormously angry, debate within a political nation now split on what had united it - the importance of the Irish parliament. One of the issues under debate was whether the Irish parliament had the constitutional right to abolish itself. Both sides turned to Blackstone to help justify their arguments.

Perhaps the earliest use of Blackstone was by an anonymous barrister who argued in late 1798 that a union would not change the constitution of Ireland 'in substance and in spirit'. Blackstone had shown that while the constitution lasted, the power of parliament was absolute. The Irish parliament therefore had the right to pass the union. ${ }^{69}$ In response, George Barnes, an anti-union barrister, used Blackstone against the union, arguing that it would violate the people's rights as it involved one parliament denying equal authority to its successors. Blackstone had demonstrated this when he said that any violation of the fundamental conditions of the Anglo-Scottish union by Westminster did not dissolve the union. The constitutional rights of parliament, Barnes argued, therefore no longer existed under the union. A union would destroy Ireland's constitution, and Blackstone said the authority of parliament ended with the constitution. It therefore had no right to pass the union. ${ }^{70}$ Subsequent usages of Blackstone on both sides followed the basic outlines of these arguments.

The pro-union speech in the Irish parliament of another barrister, William Cusack Smith, in January 1799 was the most sustained engagement with Blackstone in the union debates. Smith, who was a supporter of Catholic Emancipation, had previously opposed the union, and his change of heart may have had something to do with Pitt's

\footnotetext{
${ }^{68}$ On the passing of the union, see PM Geoghegan, The Irish Act of Union: A Study in High Politics 1798-1801 (Dublin, 1999). On the debate, WJ McCormack, The Pamphlet Debate on the Union between Great Britain and Ireland 1797-1800 (Dublin, 1996).

${ }^{69}$ [A Barrister], Letter to Joshua Spencer, Esq. Occasioned by his Thoughts on an Union (Dublin, 1798) $40-41$.

${ }^{70} \mathrm{G}$ Barnes, The Rights of the Imperial Crown of Ireland Asserted and Maintained, against Edward Cooke, Esq. reputed author of a pamphlet, entitled, Arguments for and Against an Union, \&c, in a letter to that gentleman. The second edition with additions (Dublin, 1799) 58, 73-74. Barnes referenced a fn added to the 2nd edition of Commentaries, vol 1, 323 [2nd edn, 97] where Blackstone said a state must have the right to change 'every part of its laws'; also cited by GS Smyth, First Letter to a Noble Lord on the Subject of the Union, 2nd edn (Dublin, 1799) 22.
} 
intentions to pass the two measures together. Like all published parliamentary speeches, the speech reflected what Smith wished he had said as much as what he had delivered in parliament. Large parts of Smith's arguments and examples were drawn from Blackstone, demonstrating how he thought Blackstone would add credibility to his new position, both in parliament and the wider public sphere. Smith, who attacked a number of the fundamental assumptions of official Irish political culture since 1782, argued that the existence of two legislatures produced a tendency towards separation, and that union must be enacted now to prevent this given the war with the French Republic. ${ }^{71}$

Blackstone had demonstrated the legitimacy of the Scottish union, and 'saved us the trouble' of even asking whether the Irish parliament had the power to pass a union. ${ }^{72}$ Union would change, not subvert the constitution - Ireland would still be governed by king, lords and commons, with Ireland having her due weight in the new parliament. The principles of the constitution would remain intact, the means of enacting them would differ slightly. Smith used precedents for parliament changing the constitution from Blackstone, and cited Coke and Blackstone to justify the absolute power of parliament to do so. ${ }^{73}$ The union would not rob subsequent parliaments of their power because Ireland's king, lords and commons would retain the same powers in the new arrangement. Blackstone had already demonstrated the continued existence of the constitution in the Scottish union. ${ }^{74}$ Smith even endorsed one of Blackstone's more controversial statements, arguing that every constitution indeed needed despotic power lodged somewhere. If not vested in parliament, where it being shared between the three branches prevented tyranny, then it must be lodged in the populace. That would destroy the constitution, rendering Ireland 'a despotic democracy'. ${ }^{75}$ For Smith, the union

\footnotetext{
${ }^{71}$ WC Smith, The Substance of Mr. William Smith's Speech on the Subject of a Legislative Union between this country and Great Britain; delivered in the House of Commons, on Thursday January 24 th, 1799, and now reduced to the form of an address to the people of Ireland, 5th edn (Dublin, 1799) 4.

72 ibid 25.

73 ibid 18-20. Anti-unionists argued that union would destroy the constitution and enact tyranny by leaving only one branch of the Irish legislature intact. C Molyneux, A Reply to the Memoire of Theobald McKenna, Esq. on some Questions Touching the Projected Union of Great Britain and Ireland (Dublin,
} 1799) 16-17, citing Blackstone, Commentaries vol 1, 149

74 ibid 32.

75 ibid 39. 
accorded with the true principles of the British constitution as expounded by Blackstone, Coke and Montesquieu. He painted a picture of Ireland under a union as a prosperous country with religious divisions left in the past. Blackstone lay at the heart of almost all his major arguments.

Blackstone also lay at the heart of a rebuttal of Smith in parliament. John Egan argued that anyone who believed Blackstone about the powers of parliament to vote itself out of existence also believed Blackstone that Westminster had had the right to bind Ireland (words chosen deliberately to echo Molyneux). ${ }^{76}$ Egan's argument was clever, as this was, of course, something that no member of the Irish parliament could admit. Egan drove the point home by saying that Westminster had demonstrated Blackstone's error with the 'Renunciation Act'.

While the union debates caused Irish political writers to explicitly draw on Blackstone once more, only a very small proportion of the more than three hundred pamphlets published on the question did so, probably under five percent. However, Blackstone's arguments were more influential than this number suggests. Given the prominence of barristers and barrister-politicians on both sides of the debate, and the fact that the Commentaries were now part of the educational background of the broader elite, Blackstone's arguments on the powers of parliament and on the Scottish union helped shape the terms of the debate. The argument that parliament lacked the power to vote itself out of existence did not gain wide traction. The union was originally rejected for a range of reasons, ranging from nationalism to the desire to extract more generous payment from government for one's vote. Believing the Irish parliament should not abolish itself was not the same as believing it lacked the right to do so. As Smith noted, believing this meant that the rebels won at Culloden (ie that 1688 had been illegitimate), and the Irish political elite, like the British, could never admit that. ${ }^{77}$ It was no accident that it was mainly lawyers who drew on Blackstone during the union debate in an attempt to give authority to their arguments. But these arguments were on the whole not determined by their understanding of Blackstone - rather he represented a means of gilding pre-existing arguments, for or against a union, to which they were already committed .

\footnotetext{
${ }^{76}$ Belfast Newsletter, 8th February 1799.

77 Smith, Speech 20.
} 


\section{CONCLUSION}

Irish critics of Blackstone focused primarily on combatting Blackstone's assertion of Westminster's sovereignty over Ireland by right of conquest. They felt it was important to do so because of his prominence in defining the principles of the British and Irish elites. If they could undermine Blackstone, they believed, the rest of their arguments would be more easily accepted. They challenged Blackstone's understanding of Irish history, denying a conquest had ever taken place, but also rooted their arguments in the language of natural rights, denying the existence of a right of conquest. They attacked Blackstone's understanding of the constitution and the absolute power of parliament, instead offering an account of its legitimate powers rooted in Real Whiggery. While much Irish criticism of Blackstone was superficial, Sheridan produced a much more meaningful critique that led him to offer some original ideas about natural rights and representation, and the nature of the empire. The Catholic critics of Blackstone also rejected the notion of conquest; they centred their criticisms on the idea that he did not understand Irish history and especially the accusation that he thought about Ireland and about Catholicism only in the most superficial and prejudiced way (an accusation Grattan made on the issue of conquest). Thus the two major groups of Blackstone's Irish critics voiced similar criticisms, but both also felt it necessary to mix their criticisms with an acknowledgement of Blackstone's genius.

After 1782, the main impulse to criticise Blackstone was gone. He now served primarily as a source of authority that could be drawn upon by all sides of the debate on a range of political issues. This was how engagement with Blackstone mainly functioned during the union debates, when discussion of his ideas reached a level not seen in nearly two decades. Fundamentally, however, Blackstone was being used after 1782 in highly selective ways to support arguments in which the engagement with him was often negligible. However, Smith's speech to parliament reminds us that many of the fundamental constitutional assumptions of the elite had been shaped, at least in part, by Blackstone. Combined with his influence on the elite, he had a greater influence on Irish political culture, at least in its constitutional manifestations, than is revealed by 
studying debates directly engaging with his arguments. More work on Irish constitutional thought would most likely reveal this. However, we should also remember that the mass revolutionary movement of the 1790s, the United Irishmen, essentially ignored Blackstone, as they did not seek to make their case on the grounds of the British constitution, but instead called for its overthrow. Locke's rhetoric of rights was useful for them, but not Blackstone's justification of the laws. ${ }^{78}$

Blackstone's Irish critics, then, were a diverse group, often divided among themselves, and often engaging with him at only a superficial level. Nevertheless, that engagement produced some of the more interesting political thought in late eighteenthcentury Ireland, and helped shape thinking on the major political question of the era, Ireland's relationship with Britain. Irish criticism of Blackstone helped reshape Irish patriotism in a revolutionary age.

\footnotetext{
78 On United Irish ideology, N Curtin, The United Irishmen: Popular Politics in Ulster and Dublin, 17911798 (Oxford, 1994); K Whelan, The Tree of Liberty: Radicalism, Catholicism and the Construction of Irish Identity, 1760-1830 (Cork, 1996); J Smyth, Men of No Property, 2nd edn (Basingstoke, 1998); U Gillen, 'Constructing Democratic Thought in Ireland in the Age of Revolution, 1775-1800' in J Innes and M Philp (ed), Reimagining Democracy in the Age of Revolutions: America, France, Britain, Ireland, 1750-1850 (Oxford, 2013) 149-61.
} 